\title{
PENINGKATAN KETERAMPILAN ADMINISTRASI DAN TATA KELOLA KEUANGAN APARAT DESA DI DESA SAYATI DAN DESA SUKAMENAK KECAMATAN MARGAHAYU KABUPATEN BANDUNG
}

\author{
Sri Murniati ${ }^{1}$, Endang Habinudin ${ }^{1}$, Fatmi Hediani ${ }^{1}$, Yanti Rufaedah ${ }^{1}$ \\ ${ }^{1}$ Dosen UP MKU Politeknik Negeri Bandung
}

Email: Murniati5@yahoo.com, end_hab@yahoo.co.id, fatmihadiani@yahoo.com, yantirufa@yahoo.com

\begin{abstract}
Abstrak
Agar kegiatan pemerintahan desa efektif, diperlukan pengetahuan dan keterampilan para aparatnya dalam mengerjakan tugas-tugas keadministrasian bersama kepala desa dan sekretarisnya. Untuk itu, diperlukan pelatihan. Pelatihan ini bertujuan untuk meningkatkan kemampuan dalam menulis surat yang sesuai dengan kaidah kebahasaan, kearsipan, membuat laporan keuangan desa, dan statistik kependudukan bagi para aparat desa di Desa Sayati dan Desa Sukamenak. Metode pelatihannya dilakukan dengan cara penyampaian teori dan praktik. Sebelum pelatihan dilakukan, diberikan pretes untuk evaluasi kemampuan awal dan postes sebagai evaluasi akhir. Hasil pretes menunjukkan bahwa pengetahuan keadministrasian para aparat desa tersebut belum memadai. Untuk itu, selain teori dan praktik, diberikan pula tugas mandiri secara individu sesuai dengan tugas masing-masing di kantor desa. Selain itu, diberikan tugas kelompok kemudian hasilnya dipresentasikan dan dilanjutkan dengan berdiskusi. Hal tersebut sebagai bentuk monitoring dan pendampingan. Dalam hal ini, ditunjukkan hal-hal yang belum tepat dan perbaikannya agar mereka dapat menerapkan pada tugasnya sesuai dengan yang seharusnya. Hasil pelatihan menunjukkan bahwa setelah pelatihan dilaksanakan, terdapat peningkatan pengetahuan dan keterampilan keadministrasian bagi para aparat desa di kedua desa tersebut.
\end{abstract}

Kata kunci: Tata kelola, aparat desa, statistik kependudukan

\section{PENDAHULUAN}

\section{Latar Belakang}

Agar kegiatan pemerintahan desa efektif, diperlukan keterampilan para aparat- nya dalam mengerjakan tugas-tugas keadministrasian untuk mencapai tujuan yang telah ditetapkan Berdasarkan Peraturan Menteri dalam Negeri No. 32 Tahun 2006, tentang pedoman Administrasi Desa, yaitu, "Administrasi desa 
DIFUSI

Volume 2, No.2 Juli 2019

adalah keseluruhan kegiatan proses pencatatan data dan informasi mengenai penyelenggaraan pemerintahan desa pada buku administrasi desa. "Jenis administrasi desa adalah Admnistrasi umum, administrasi kependudukan, administrasi keuangan, administrasi BPD, dan Administrasi Pembangunan. Administrasi umum berkaitan erat dengan penulisan surat dan kearsipan. Admiistrasi kependudukan berkaitan erat dengan penggunaan statistika, yaitu dalam penulisan data kependudukan, yang biasanya berupa tabel. Administrasi keuangan berkaitan erat dengan akuntansi, yaitu pelaporan keuangan di desa tersebut. Administrasi BPD berisi pencatatan data dan informasi tentang BPD. Administrasi pembangunan berisi pencatatan dan informasi tentang pembangunan.

Berdasarkan hasil survei di desa Sayati dan desa Sukamenak, diketahui bahwa pelaksanaan administrasi pada kedua desa tersebut belum optimal. Sebagai contoh, pada pengelolaan administrasi kependudukan, terjadi ketidakcocokan data dalam tabel dengan data riil dan masih dituliskan dalam bentuk manual.

Padahal, pemerintah desa/kelurahan bertugas menyelenggarakan sebagian urusan administrasi kependudukan dan sering diminta oleh instansi lainnya, misalnya Badan Pusat Statistik (BPS) untuk tujuan khusus instansi tersebut (Dewi dan Amrun, 2010). Begitu pula laporan keuangan dan kearsipannya belum tertib. Selain itu, penulisan surat - surat resmi, seperti surat undangan, surat pemberitahuan, belum menggunakan bahasa Indonesia yang baik dan benar. Hal tersebut dapat menyebabkan kurang komunikatifnya penyampaian informasi maupun laporan-laporan yang harus disampaikan kepada pihak-pihak yang terkait. Aparat desa masih sedikit yang pernah mengikuti pelatihan serupa. Selain itu, desa Sayati memiliki empat buah komputer dan desa Sukamenak memiliki tiga buah komputer. Akan tetapi, keterampilam aparat desa untuk mengoperasikan komputer masih terbatas. Sementara, pelayanan administrasi bagi warga dan jajarannya diperlukan hampir setiap hari dan hampir di segala unit, sterutama surat. Hal tersebut merupakan kendala bagi terlaksananya penyelenggaraan pemerintahan desa. Untuk itu, perlu dilakukan pelatihan tentang empat materi tersebut.

\section{Rumusan Masalah}

Bedasarkan analisis situasi pada latar belakang tersebut, dapat dirumuskan permasalahan sebagai berikut.

a. Kurangnya pengetahuan dan keterampilan para aparat desa dalam penulisan surat dengan menggunakan bahasa Indonesia yang baik dan benar.

b. Kurangnya pengetahuan dan keterampilan para aparat desa dalam kearsipan.

c. Kurangnya pengetahuan dan keterampilan para aparat desa dalam membuat laporan keuangan.

d. Kurangnya Pengetahuan dan keterampilan para aparat dalam pengerjaan statistik kependudukan dengan software Microsoft Excel.

\section{Tujuan Pelatihan}

Sesuai dengan rumusan masalah tersebut, tujuan pelatihannya sebagai berikut. 
DIFUSI

Volume 2, No.2 Juli 2019

a. Meningkatkan kemampuan para aparat desa dalam menulisa surat dengan menggunakan bahasa Indonesia yang baik dan benar;

b. Meningkatkan keterampilan para aparat desa dalam kearsipan;

c. Meningkatkan keterampilan para aparat desa dalam membuat laporan keuangan desa;

d. Meningkatkan keterampilan para aparat desa dalam pengerjaan statistik kependudukan dengan software Microsoft excel.

\section{TARGET DAN LUARAN}

Program ini dilakukan melalui pelatihan dengan judul "Pelatihan Peningkatan Keterampilan Administrasi dan Tata Kelola Keuangan Aparat Desa di Desa Sayati dan Desa Sukamenak, Kecamatan Margahayu, Kabupaten Bandung." Materi pelatihan dikemas dalam bentuk modul dan dibagikan kepada para peserta sebagai panduan dalam pelatihan. Untuk mengukur keberhasilannya, dilakukan evaluasi peserta berupa praktik mengenai keempat materi pelatihan tersebut dan diberikan kuesioner kepada para aparat desa yang menjadi peserta pelatihan. Peserta yang memenuhi syarat, yaitu dalam kehadiran, ketertiban saat pembelajaran, dan dalam mengikuti proses pembelajaran dengan baik, diberikan penghargaan berupa sertifikat.

\section{Target}

Diharapkan, kegiatan ini akan memberikan manfaat seperti berikut.

\section{a. Bagi Mitra}

1) Meningkatkan wawasan dan keterampilan para aparat desa dalam hal kemampuan membuat surat menggunakan bahasa Indonesia yang baik dan benar;

2) Meningkatkan wawasan dan keterampilan aparat desa dalam hal kemampuan mengolah data dengan statistik sederhana sehingga data dapat ditampilkan dalam bentuk yang menarik dan mudah dipahami oleh masyarakat.

3) Meningkatkan wawasan dan keterampilan aparat desa dalam menyususn laporaan keuangan yang mudah dipahami;

4) Meningkatkan wawasan dan keterampilan aparat desa dalam hal kemampuan mengarsip dokumen dengan baik sehingga mudah diperoleh apabila sewaktu-waktu dibutuhkan.

\section{b. Bagi Polban}

1) Memperkenalkan Polban sebagai perguruan tinggi yang melaksanakan pendidikan pada jalur vokasi;

2) Mendapatkan kesempatan dalam meningkatkan peran dosen dari berbagai bidang ilmu untuk bekerja sama dengan pihak aparat desa di Desa Sayati dan Desa Sukamenak, Kecamatan Margahayu, Kabupaten Bandung dalam kegiatan pengabdian kepada masyarakat.

3) Memperkenalkan Polban sebagai perguruan tinggi yang melaksanakan pendidikan pada jalur vokasi;

4) Mendapatkan kesempatan dalam meningkatkan peran dosen dari 
DIFUSI

Volume 2, No.2 Juli 2019

berbagai bidang ilmu untuk bekerja sama dengan pihak aparat desa di Desa Sayati dan Desa Sukamenak, Kecamatan Margahayu, Kabupaten Bandung dalam kegiatan pengabdian kepada masyarakat.

\section{Luaran}

Luaran dari pelatihan ini adalah jasa pelatihan. Para peserta yang mengikuti pelatihan dan memenuhi standar evaluasi yang ditetapkan dapat memperoleh sertifikat. Dampak sosial dari kegiatan pelatihan ini adalah diharapkan dapat meningkatkan kemampuan dan keterampilan peserta pelatihan dalam menulis surat resmi dengan bahasa Indonesia yang baik dan benar, keterampilan dalam mengarsipkan dokumen dengan efisien dan efektif, keterampilan dalam menyusun laporan keuangan, keterampilan olah data dengan statistik. Dengan kemampuan tersebut, diharapkan para aparat desa dapat meningkatkan fungsinya dalam melayani masyarakat di tingkat desa mengingat fungsi desa sebagai ujung tombak pemerintahan. Selain itu, dapat meningkatkan silaturahmi antara para aparat desa Desa Sayati dan Desa Sukamenak (masyarakat), dan penyelenggara pelatihan (akademisi), dalam hal ini pihak Polban.

\section{METODE PELAKSANAAN}

\section{Alur Kegiatan}

Identifikasi kemampuan awal peserta (pretes) tentang penulisan surat resmi penyampaian materi surat dan bahasa surat resmi, praktik dan pembahasan

\section{Praktik dan pembahasan Laporan Keuangan \\ Postes laporan keuangan Pretes statistika kependudukan}

postes materi surat pretes materi Kearsipan penyampaian materi kearsipan praktik dan pembahasan kearsipan

Praktik dan pembahasan kearsipan postes kearsipan pretes Laporan Keuangan penyampaian materi laporan keuangan

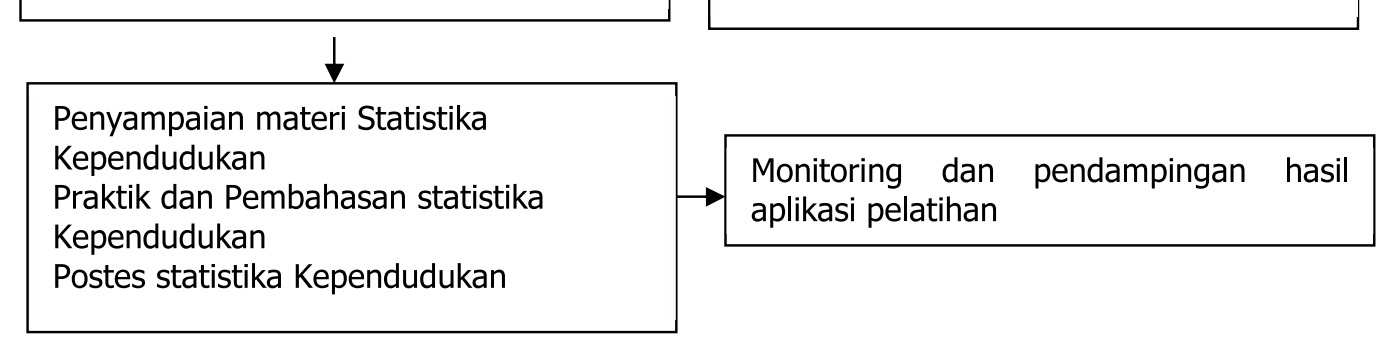

Gambar 1. Alur Kegiatan Pelatihan 
DIFUSI

Volume 2, No.2 Juli 2019

\section{Evaluasi Program Kegiatan}

Tabel 1. Evaluasi Program Kegiatan

\begin{tabular}{|c|c|c|}
\hline No. & JENIS EVALUASI & KETERANGAN \\
\hline 1. & Evaluasi program & $\begin{array}{l}\text { Dilakukan sebelum dan setelah kegiatan dilaksanakan. Evaluasi } \\
\text { ini bertujuan untuk mengetahui kesesuaian program kegiatan } \\
\text { dengan tujuan yang akan dilaksanakan. }\end{array}$ \\
\hline 2 & Evaluasi proses & $\begin{array}{l}\text { Dilakukan pada saat kegiatan berlangsung. Aspek yang } \\
\text { dievaluasi adalah kehadiran dan aktivitas peserta dalam } \\
\text { mengikuti pelatihan. }\end{array}$ \\
\hline 3 & Evaluasi hasil & $\begin{array}{l}\text { Dilaksanakan pada setiap akhir pemberian materi berupa } \\
\text { postes. Pada akhir kegiatan, dilakukan pengamatan pada } \\
\text { aplikasi keempat materi pada tugas keseharian para aparat di } \\
\text { desa masing-masing dengan dilakukan monitoring dan } \\
\text { pendampingan. }\end{array}$ \\
\hline
\end{tabular}

\section{PELAKSANAAN KEGIATAN}

\section{Kegiatan Pelatihan}

Kegiatan pengabdian kepada masyarakat ini dilaksanakan dalam bentuk pelatihan yang diawali dengan pemberian pretes, pembahasan hasil pretes dilanjutkan dengan penyampaian teori dan praktik beserta pembahasan hasil praktik, dan evaluasi/postes.

Dalam monitoring dan pendampingan, peserta mengerjakan tugas pengaplikasian materi yang telah diajarkan pada tugas-tugas keseharian di kantor desa. Tugas-tugas tersebut dibahas dan diberi masukan, diberikan penjelasan sekaligus ditunjukkan bagian yang masih keliru dan ditunjukkan yang seharusnya.

Mengingat materinya banyak, sedangkan waktunya terbatas, pelaksanaan pelatihan dilakukan dengan pemadatan secara aplikatif. Dalam hal ini, kegiatan lebih ditekankan banyak praktik dan pembahasan. Hal tersebut bertujuan agar para peserta dapat langsung memahami materi dan dapat mengaplikasikannya pada tugas keseharian di desa masing-masing.

Selain penilaian hasil aplikasi materi pelatihan, peserta juga dievaluasi aktivitasnya selama mengikuti serangkaian pelatihan, yaitu absensi kehadiran dan ketepatan waktu mengikuti setiap sesi pelatihan selama mengikuti pelatihan.

\section{Data Hasil Tes}

Untuk memperoleh gambaran hasil sebelum dan sesudah mengikuti pelatihan, dilakukan analisis statistika sederhana (uji t) berdasarkan materi-materi yang sudah diajarkan. Berdasarkan hasil tes/evaluasi yang diberikan secara tertulis dan praktik, keterampilan para aparat desa Desa Sayati dan Desa Sukamenak dalam keadministrasian dan pelaporan keuangan meningkat. Hasilnya dapat ditunjukkan pada Tabel 2. 
DIFUSI

Volume 2, No.2 Juli 2019

Tabel 2. Nilai Pretes dan Postes Peserta Pengabdian kepada Masyarakat

\begin{tabular}{|c|c|c|c|c|c|c|c|c|c|}
\hline \multirow{2}{*}{ NO. } & \multirow{2}{*}{ NAMA } & \multicolumn{2}{|c|}{ Surat Menyurat } & \multicolumn{2}{|c|}{ Kearsipan } & \multicolumn{2}{|c|}{$\begin{array}{l}\text { Laporan } \\
\text { Keuangan }\end{array}$} & \multicolumn{2}{|c|}{ Kependudukan } \\
\hline & & Pretes & Postes & Pretes & Postes & Pretes & Postes & Pretes & Postes \\
\hline 1 & Agung Rudini & 50 & 68 & 56 & 80 & 73 & 75 & 50 & 60 \\
\hline 2 & Ayang Budi D. & 60 & 70 & 70 & 90 & 53 & 75 & 60 & 70 \\
\hline 3 & Dadang Suwita & 60 & 70 & 70 & 90 & 60 & 50 & 60 & 70 \\
\hline 4 & Dena Wahyu K. & 60 & 75 & 60 & 80 & 53 & 70 & 50 & 70 \\
\hline 5 & Dewi Ikawati & 70 & 80 & 57 & 75 & 67 & 70 & 50 & 60 \\
\hline 6 & Eko Ismail & 56 & 65 & 70 & 85 & 60 & 60 & 50 & 60 \\
\hline 7 & Engkun Sodikin & 60 & 75 & 56 & 75 & 67 & 80 & 60 & 60 \\
\hline 8 & Firman Hamdani & 50 & 68 & 60 & 85 & 100 & 100 & 70 & 80 \\
\hline 9 & Fratika Supanji & 55 & 80 & 60 & 75 & 40 & 62 & 40 & 60 \\
\hline 10 & Ilham Ansori & 65 & 70 & 56 & 70 & 55 & 70 & 50 & 60 \\
\hline 11 & Imas Pujiah & 56 & 65 & 60 & 75 & 80 & 68 & 60 & 70 \\
\hline 12 & Kurniawan & 58 & 65 & 56 & 70 & 60 & 70 & 50 & 60 \\
\hline 13 & Lukman Nurhakim & 65 & 70 & 60 & 80 & 73 & 75 & 60 & 70 \\
\hline 14 & Mia Monika & 58 & 65 & 60 & 70 & 58 & 68 & 60 & 60 \\
\hline 15 & Nurhayati & 65 & 75 & 70 & 80 & 53 & 65 & 50 & 70 \\
\hline 16 & Peri Permadi & 65 & 80 & 56 & 80 & 98 & 100 & 60 & 80 \\
\hline 17 & Robi & 50 & 60 & 56 & 70 & 53 & 60 & 50 & 60 \\
\hline 18 & Setia Putra & 58 & 65 & 56 & 70 & 56 & 68 & 60 & 70 \\
\hline 19 & Sofa Soprowi & 60 & 75 & 56 & 75 & 33 & 65 & 40 & 60 \\
\hline \multirow[t]{2}{*}{20} & Yudi Permana & 56 & 65 & 56 & 75 & 55 & 70 & 50 & 60 \\
\hline & RATA-RATA & $\mathbf{5 8 , 8 5}$ & 70,3 & 60,05 & 77,5 & 62,35 & 71,05 & 54 & 65,5 \\
\hline
\end{tabular}

Berdasarkan tabel tersebut, dapat dilihat bahwa pada setiap materi terdapat kenaikan dari sebelum dan sesudah pelatihan. Pada materi Surat, terdapat kenaikan $19 \%$, pada materi Kearsipan, terdapat kenaikan 29\%, pada materi Laporan Keuangan, terdapat kenaikan sebesar 14\%, dan pada materi Statistika kependudukan 21\%. Rata-rata secara keseluruhan, terdapat kenaikan 20,75\%. Dengan demikian, terdapat peningkatan keterampilan bagi para aparat desa tersebut walaupun belum signifikan. Dimungkinkan, hal tersebut karena keterbatasan waktu pelatihan yang tersedia.

\section{Uji t}

Uji $\mathrm{t}$ atau t-test adalah analisis yang melibatkan dua pengukuran pada subjek yang sama terhadap suatu pengaruh atau perlakuan tertentu. Pengukuran pertama dilakukan sebelum diberi perlakuan tertentu, yaitu pretes dan pengukuran kedua dilakukan sesudahnya, yaitu postes. Dasar pemikirannya sederhana, yaitu apabila suatu perlakuan tidak memberi pengaruh, perbedaan rata-rata adalah 0 . Uji t dua sampel independen adalah jenis uji statistika parametric yang bertujuan untuk menguji terdapatnya perbedaan atau tidak dari rata-rata antara dua 
DIFUSI

Volume 2, No.2 Juli 2019

kelompok data yang berpasangan. Sampel berpasangan adalah bila dua buah data yang akan dibandingkan berasal dari individu yang sama. Pengukurannya sebanyak dua kali, yaitu sebelum perlakuan (pretes) dan setelahperlakuan (postes).

Uji t dua sampel berpasangan memiliki beberapa persyaratan:

1. Data harus berdistribusi normal;

2. Kedua sampelnya berpasangan;

3. Tipe data numerik.

Berdasarkan data hasil evaluasi pelatihan, persyaratan tersebut telah terpenuhi, anatara lain, data sudah bersekala numerik (angka). Kedua sampel berpasangan yaitu sebelum pelatihan dan setelah pelatihan. Hal tersebut dapat dilihat pada uraian hasil analisis pada keempat materi berikut.

\section{Materi 1. Surat-Menyurat}

Dengan analisis menggunakan software SPSS, diperlihatkan data pretes dan postes berdistribusi normal.

Hipotesis:

$\mathrm{HO}$ : Tidak terdapat perbedaan kemampuan sebelum dan sesudah pelatihan

H1 : Terdapat perbedaan kemampuan sebelum dan sesudah pelatihan

Berdasarkan output SPSS dapat disimpulkan bahwa rata-rata nilai pretes peserta pelatihan 58,85 dan rata-rata nilai postes 70,30. Hasil ini menunjukkan peningkatan yang cukup signifikan. Berdasarkan nilai korelasi, dapat disimpulkan bahwa terdapat korelasi antara nilai pretes dan nilai postes sebesar 0,60 . Hal tersebut menunjukan kuatnya hubungan nilai pretes dan nilai postes.

Analisis Paired Test memperlihatkan memperlihatkan bahwa terjadi perbedaan nilai yang signifikan mengenai kemampuan peserta dalam menulis surat dengan bahasa Indonesia yang baik dan benar sebelum dan setelah pelatihan. Berdasarkan nilai thitung dan nilai tabel sebagai berikut:

$t_{\text {hitung }}=-10,07<t_{\text {tabel }}=2,09$

(dengan $\mathrm{dk}=21$ )

Karena nilai thitung lebih kecil dari nilai $t_{\text {tabel}}$, Ho ditolak. Dapat dikatakan bahwa terdapat perbedaan kemampuan sebelum dan sesudah pelatihan, yaitu keterampilan para peserta dalam penulisan surat dengan menggunakan bahasa Indonesia yang benar meningkat.

\section{Materi 2. Kearsipan}

Dengan analisis menggunakan software SPSS, dapat diperlihatkan bahwa data pretes dan postes berdistribusi normal, seperti berikut.

Hipotesis:

$\mathrm{H}_{0}$ : Tidak terdapat pebedaan kemampuan sebelum dan sesudah pelatihan

$\mathrm{H}_{1}$ : Terdapat perbedaan kemampuan sebelum dan sesudah pelatihan 
DIFUSI

Volume 2, No.2 Juli 2019

Hasil Olah Data :

Tabel 1. Paired Samples Statistics

\begin{tabular}{|ll|r|r|r|r|}
\hline & & Mean & $\mathrm{N}$ & Std. Deviation & Std. Error Mean \\
\hline Pair & Pretes & 60.0500 & 20 & 5.39469 & 1.20629 \\
1 & Postes & 77.5000 & 20 & 6.38666 & 1.42810 \\
\hline
\end{tabular}

Tabel 2. Paired Samples Correlations

\begin{tabular}{|ll|r|r|r|}
\hline & \multicolumn{1}{|c|}{ N } & Correlation & \multicolumn{1}{c|}{ Sig. } \\
\hline Pair 1 & Pretes \& Postes & 20 & .745 & .000 \\
\hline
\end{tabular}

Tabel 3. Paired Samples Test

\begin{tabular}{|c|c|c|c|c|c|c|c|c|c|}
\hline & & \multicolumn{5}{|c|}{ Paired Differences } & \multirow[b]{3}{*}{$\mathrm{t}$} & \multirow[b]{3}{*}{ df } & \multirow{3}{*}{$\begin{array}{l}\text { Sig. }(2- \\
\text { tailed) }\end{array}$} \\
\hline & & \multirow[b]{2}{*}{ Mean } & \multirow{2}{*}{$\begin{array}{c}\text { Std. } \\
\text { Deviation }\end{array}$} & \multirow{2}{*}{$\begin{array}{l}\text { Std. Error } \\
\text { Mean }\end{array}$} & \multicolumn{2}{|c|}{$\begin{array}{l}95 \% \text { Confidence Interval of } \\
\text { the Difference }\end{array}$} & & & \\
\hline & & & & & Lower & Upper & & & \\
\hline $\begin{array}{l}\text { Pair } \\
1\end{array}$ & $\begin{array}{l}\text { Pretes } \\
\text { Postes }\end{array}$ & $\begin{array}{r}- \\
17.45000\end{array}$ & 4.31003 & .96375 & -19.46715 & -15.43285 & $\begin{array}{r}- \\
18.106\end{array}$ & 19 & .000 \\
\hline
\end{tabular}

Pada tabel hasil olah data tersebut, dapat dilihat bahwa rata-rata nilai pretes peserta pelatihan 60,05 dan rata-rata nilai postes 77,50. Hasil ini menunjukkan peningkatan yang cukup signifikan. Berdasarkan nilai korelasi, dapat disimpulkan bahwa terdapat korelasi antara nilai pretes dan nilai postes sebesar 0,74 Hal tersebut menunjukan kuatnya hubungan nilai pretes dan nilai postes. Analisis paired test memperlihatkan bahwa terjadi perbedaan nilai yang signifikan mengenai kemampuan peserta dalam pengarsipan sebelum dan setelah pelatihan. Berdasarkan nilai terhitung dan nilai ttabel sebagai berikut:

$\mathrm{t}_{\text {hitung }}=-18,10<\mathrm{t}_{\text {tabel }}=2,09$

(dengan $\mathrm{dk}=21$ )
Karena nilai thitung lebih kecil dari nilai $t_{\text {tabel}}, \mathrm{H} 0$ ditolak. Dapat dikatakan bahwa terdapat perbedaan kemampuan sebelum dan sesudah pelatihan, yaitu keterampilan para peserta dalam pengarsipan meningkat.

\section{Materi 3. Laporan Keuangan}

Dengan analisis menggunakan software SPS diperlihatkan bahwa data pretes dan postes berdistribusi normal, seperti berikut.

Hipotesis:

HO : Tidak terdapat perbedaan kemampuan sebelum dan sesudah pelatihan

H1 : Terdapat perbedaan kemampuan sebelum dan sesudah pelatihan 
DIFUSI

Volume 2, No.2 Juli 2019

Tabel 4. Paired Samples Statistics

\begin{tabular}{|rr|r|r|r|r|}
\hline & & Mean & \multicolumn{1}{|c|}{ N } & Std. Deviation & Std. Error Mean \\
\hline Pair 1 & Pretes & 62.3500 & 20 & 16.48692 & 3.68659 \\
& Postes & 71.0500 & 20 & 11.87423 & 2.65516 \\
\hline
\end{tabular}

Tabel 5. Paired Samples Correlations

\begin{tabular}{|ll|r|r|r|}
\hline & \multicolumn{1}{|c|}{ N } & Correlation & \multicolumn{1}{c|}{ Sig. } \\
\hline Pair 1 & Pretes \& Postes & 20 & .760 & .000 \\
\hline
\end{tabular}

Tabel 6. Paired Samples Test

\begin{tabular}{|c|c|c|c|c|c|c|c|c|c|}
\hline & & \multicolumn{5}{|c|}{ Paired Differences } & \multirow[b]{3}{*}{$\mathrm{t}$} & \multirow[b]{3}{*}{$\mathrm{df}$} & \multirow{3}{*}{$\begin{array}{l}\text { Sig. (2- } \\
\text { tailed) }\end{array}$} \\
\hline & & \multirow[b]{2}{*}{ Mean } & \multirow{2}{*}{$\begin{array}{c}\text { Std. } \\
\text { Deviation }\end{array}$} & \multirow{2}{*}{$\begin{array}{l}\text { Std. } \\
\text { Error } \\
\text { Mean }\end{array}$} & \multicolumn{2}{|c|}{$\begin{array}{c}95 \% \text { Confidence Interval } \\
\text { of the Difference }\end{array}$} & & & \\
\hline & & & & & Lower & Upper & & & \\
\hline $\begin{array}{l}\text { Pair } \\
1\end{array}$ & $\begin{array}{l}\text { Pretes } \\
- \\
\text { Postes }\end{array}$ & -8.70000 & 10.73166 & 2.39967 & -13.72257 & -3.67743 & -3.625 & 19 & .002 \\
\hline
\end{tabular}

Tabel 7. Paired Samples Statistics

\begin{tabular}{|ll|r|r|r|r|}
\hline & \multicolumn{1}{|c|}{ Mean } & \multicolumn{1}{|c|}{ N } & Std. Deviation & Std. Error Mean \\
\hline Pair 1 & Pretes & 54.0000 & 20 & 7.53937 & 1.68585 \\
& Postes & 65.5000 & 20 & 6.86333 & 1.53469 \\
\hline
\end{tabular}

Pada tabel hasil olah data tersebut, dapat dilihat bahwa rata-rata nilai pretes peserta pelatihan 62.35 dan rata-rata nilai postes 71.05. Hasil ini menunjukkan peningkatan yang cukup signifikan. Berdasarkan nilai korelasi, dapat disimpulkan bahwa terdapat korelasi antara nilai pretes dan nilai postes sebesar 0,76 . Hal tersebut menunjukan kuatnya hubungan nilai pretes dan nilai postes. Analisis paired test memperlihatkan bahwa terjadi perbedaan nilai yang signifikan mengenai kemampuan peserta dalam menyusun laporan keuangan dana desa sebelum dan setelah pelatihan. Berdasarkan nilai $t_{\text {hitung }}$ dan nilai $t_{\text {tabel }}$ sebagai berikut: $\mathrm{t}_{\text {hitung }}=-3.625<\mathrm{t}_{\text {tabel }}=2,09$

(dengan $\mathrm{dk}=21$ )

Karena nilai thitung lebih kecil dari nilai ttabel, Ho ditolak. Dapat dikatakan bahwa terdapat perbedaan kemampuan sebelum dan sesudah pelatihan, yaitu keterampilan para peserta dalam menyusun laporan keuangan dana desa meningkat.

\section{Materi 4. Statistik Kependudukan}

Hipotesis:

HO : Tidak terdapat pebedaan kemampuan sebelum dan sesudah pelatihan

H1 : Terdapat perbedaan kemampuan sebelum dan sesudah pelatihan 
DIFUSI

Volume 2, No.2 Juli 2019

Tabel 8. Paired Samples Correlations

\begin{tabular}{|c|c|c|c|}
\hline & $\mathrm{N}$ & Correlation & Sig. \\
\hline Pair 1 Pretes \& Postes & 20 & .671 & .001 \\
\hline
\end{tabular}

Tabel 9. Paired Samples Test

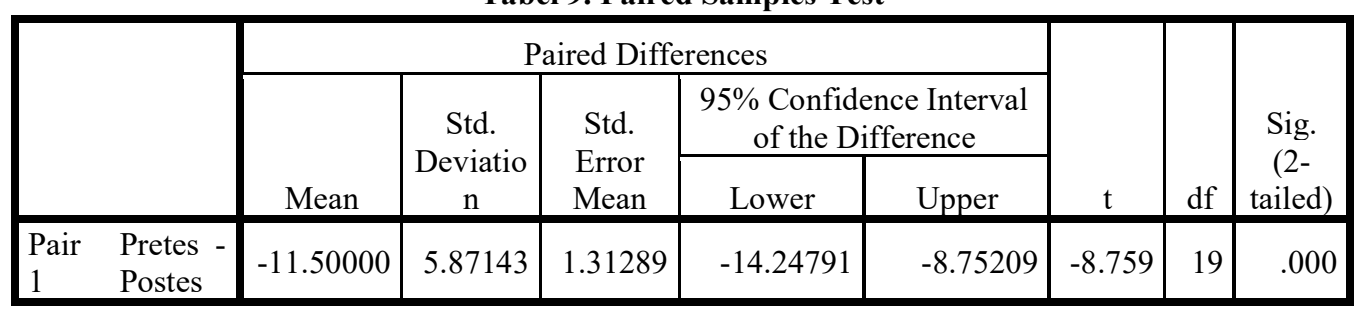

Pada tabel hasil olah data tersebut, dapat dilihat bahwa rata-rata nilai pretes peserta pelatihan 54.00 dan rata-rata nilai postes 65.50 . Hasil ini menunjukkan peningkatan yang cukup signifikan. Berdasarkan nilai korelasi, dapat disimpulkan bahwa terdapat korelasi antara nilai pretes dan nilai postes sebesar 0,67 . Hal tersebut menunjukkan hubungan nilai pretes dan nilai postes dengan kekuatan sedang. Analisis paired test memperlihatkan bahwa terjadi perbedaan nilai yang signifikan mengenai kemampuan peserta dalam mengolah data dengan statistik kependudukan sebelum dan setelah pelatihan. Berdasarkan nilai $t_{\text {hitung }}$ dan nilai tabel sebagai berikut:

$\mathrm{t}_{\text {hitung }}=-8.759<\mathrm{t}_{\text {tabel }}=2,09$

(dengan $\mathrm{dk}=21$ )

Karena nilai thitung lebih kecil dari nilai tabel, Ho ditolak. Dapat dikatakan bahwa terdapat perbedaan kemampuan sebelum dan sesudah pelatihan, yaitu keterampilan para peserta dalam mengolah data dengan statistik kependudukan meningkat.

\section{Penjelasan Hasil Kuesioner/ Angket}

Keberhasilan pengabdian yang dilakukan, selain dinilai dari hasil pretes dan postes juga melalui masukan atau pendapat peserta yang merupakan hasil jawaban angket dan evaluasi tertulis maupun praktik tentang materi-materi pelatihan. Dalam hal ini, tim pengabdian memberikan angket yang diisi oleh para peserta pelatihan sebagai responden.

Berdasarkan hasil jawaban kuesioner dari peserta tentang pelaksanaan pelatihan, dapat disimpulkan bahwa paserta pelatihan (para aparat desa) sangat antusias dalam menyimak keempat materi yang diajarkan. Mereka berpendapat bahwa materi yang disampaikan sangat padat dan sesuai dengan yang dibutuhkan dalam pengembangan pengetahuan dan keterampilan para aparat desa saat ini. Mereka juga merasakan mudah dalam mengikuti dan memahami materi yang diajarkan.

Dengan penyampaian materi yang mudah dipahami, para peserta merasa sangat terbantu dalam memahami materi 
DIFUSI

Volume 2, No.2 Juli 2019

sehingga semua materi yang direncanakan dapat terselesaikan. Penguasaan materi dari para pelatih pun sudah dianggap baik oleh para peserta sehingga dikatakan menarik dan tidak monoton. Di samping itu, semua pelatihan soal pun dapat terselesaikan meskipun waktunya terbatas. Para peserta juga sangat terbantu dalam kegiatan belajar sehingga aktif ketika berpraktik pada setiap materi karena pendampingan pemateri sangat baik. Hal tersebut dibuktikan dengan hasil angket bahwa 90\% peserta menyatakan demikian. Selain itu, mereka menyatakan bahwa praktik yang diberikan oleh pemateri sudah memadai.

Sistem kerja panitia sudah kompak sehingga pelatihan terkoordinasi dengan baik. Hal tersebut dibuktikan dengan hasil angket, yaitu $60 \%$ peserta menyatakan sangat setuju, 35\% setuju, dan 5\% menyatakan kurang setuju. Pelaksanaan kegiatan pelatihan dikatakan terkoordinasi dengan baik. Demikian pula, sarana pelatihan sangat memadai sehingga pelatihan pun terlaksana dengan baik dan lancer sesuai dengan yang direncanakan.

Saran para aparat desa dan kedua Kepala Desa (Kades Sayati dan Kades Sukamenak) diharapkan pelatihan dilaksanakan lagi dengan perluasan materi agar para aparat lebih mahir dalam melaksanakan tugas keseharian di kantornya. Bahkan, kedua Kades tersebut mengharapkan kepada tim pengabdian untuk bersedia menjadi tutor jika nanti diadakan pelatihan serupa.

\section{KESIMPULAN DAN SARAN}

Setelah kegiatan pengabdian kepada masyarakat dalam bentuk pelatihan selesai dilakukan, dapat disimpulkan sebagai berikut.

1. Bertambahnya pengetahuan dan keterampilan para aparat desa di Desa Sayati dan Desa Sukamenak dalam penulisan surat dengan bahasa Indonesia yang baik dan benar, kearsipan, laporan keuangan desa, dan penyajian data kependudukan. Hal tersebut ditunjukkan dengan terdapatnya kenaikan dari hasil pretes ke postes keempat materi yaitu sebanyak 20,75\%. Selain itu, hasil uji statistik juga menunjukkan hasil peningkatan yang signifikan.

2. Secara keseluruhan, pengabdian kepada masyarakat yang dilakukan dalam bentuk pelatihan "Peningkatan Keterampilan Administrasi dan Tata Kelola Keuangan Aparat Desa Sayati dan Desa Sukamenak, Kecamatan Margahayu, Kabupaten Bandung" dapat dikatakan terlaksana dengan baik. Hal tersebut dibuktikan dengan hasil kuesioner yang telah disampaikan di atas.

3. Diperolehnya informasi bahwa desa akan menerima bantuan dana dari pemerintah pusat (tidak dapat disebutkan jumlahnya), diperlukan kemampuan yang memadai dari para aparat desa untuk membuat laporan keadministrasiannya. Selain itu, ditemukan permasalahan sampah dan sanitasi di lingkungan desa Sukamenak.

\section{Saran}

\section{Kesimpulan}


DIFUSI

Volume 2, No.2 Juli 2019

Beberapa saran yang dapat disampaikan bagi pengabdian kepada masyarakat ini sebagai berikut.

1. Diperlukan penambahan waktu dalam pelaksanaan kegiatan pengabdian kepada masyarakat agar materi pembelajaran dapat dibahas lebih mendalam dan lebih menarik lagi.

2. Mengingat pentingnya keterampilan para aparat desa dalam hal menulis surat dengan bahasa Indonesia yang baik dan benar, khususnya bagi sekretaris desa, diperlukan materi lanjutan. Hal tersebut karena hampir setiap hari mereka harus membuat surat. Demikian pula, materi lanjutan laporan keuangan karena desa akan mendapatkan bantuan dana dari pemerintah yang harus dikelola di desa masing-masing.

3. Mengingat desa sebagai unsur pemerintahan terendah, kegiatan pengabdian kepada masyarakat ini perlu diperluas lagi ke jenjang pemerintahan yang lebih tinggi, yaitu kecamatan dan kabupaten sebagai institusi yang saling terkait.

4. Untuk mengantisipasi kebutuhan pelayanan masyarakat di tingkat desa yang lebih akurat dan cepat, diperlukan peningkatan kompetensi para aparat desa di bidang keadministrasian dan teknologi informasi agar pengelolaan dana desa dapat dilaksanakan secara akuntabel.

5. Bagi pelaksana kegiatan pengabdian kepada masyarakat berikutnya di desa tersebut, dapat memilih permasalahan keadministrasian yang ditopang dengan teknologi informasi selain permasalahan sampah dan sanitasi.

\section{UCAPAN TERIMA KASIH}

1. UPPM Polban yang telah memberikan dana dalam kegiatan pengabdian kepada masyarakat.

2. Kepala Desa Sukamenak dan Kepala Desa Sayati beserta aparatnya yang telah bersedia menjad i mitra dalam pelaksanaan kegiatan pengabdian kepada masyarakat.

3. Rekan-rekan anggota tim yang telah bekerja sama dengan baik selama pelaksanaan kegiatan pengabdian kepada masyarakat.

\section{REFERENSI}

[1] Amsyah, Zulkifli.2003. Manajemen Kearsipan. Jakarta : Gramedia.

[2] Badan Pengembangan dan Pembinaan Bahasa Kementrian Pendidikan dan Kebudayaan.2011. Buku Praktis Bahasa Indonesia 2. Edisi Pertama., Cet. Kedua. Jakarta.

[3] Bagjana, Indra Firmansyah. 2015. "Cara Mudah Menjurnal Akuntansi- Akuntansi Keuangan Desa".

[4] Dewi, A. S. dan M. Amrun, Membangun Sistem Informasi Desa, Combine Resourch Institution, 2010.

[5] Finoza, Lamudin.1991. Aneka Surat Sekretaris dan Bisnis Indonesia. Jakarta : Diksi Insan Mulia.

[6] Irma. 2010. "Pengertian Penduduk" http://irma5.blogdetik.com /files/2009/10/pkn11.pdf Diunduh 7 September 2016.

[7] Komarudin. 2003. Manajemen Kantor. Bandung : Trigenda Karya. 2003.

[8] Peraturan Menteri Dalam Negeri No.32 Tahun 2004. Tentang Pedoman Administrasi Desa. 
DIFUSI

Volume 2, No.2 Juli 2019

[9] Permendagri Nomor 113 Tahun 2014 tentang Pengelolaan Keuangan Desa.

[10] Sartika, dkk (2012), Pelatihan MS Office danSoftware Winplot Bagi Guru Matematika SMP Se Kota Cimahi, Laporan Akhir Program Pengabdian Pada Masyarakat, Polban.

[11] Setiady, Doddy. 2015. "Pedoman Asistensi Akuntansi Keuangan Desa". KASP : Ikatan Akuntan Indonesia.

[12] Suprapto. 2004. Pedoman Lengkap Surat Menyurat Bahasa Indonesia, Surabaya : Indah.

[13] Suraja,Yohannes. 2012. "Manajemen Kearsipan". http://yohannessuraja.blogspot.com/2012/09/manaj emen kearsipan. Diunduh 29 Sept 2016.
[14] Tim Perwakilan Badan Pengawasan Keuangan dan Pembangunan (BPKP). 2014. Buku Saku Pedoman Pengelolaan Keuangan Desa.

[15] Undang-Undang Republik Indonesia No.32, Tahun 2006. Tentang Pemerintah Desa

[16]Undang-Undang Republik Indonesia No.23, Tahun 2006. Tentang Administrasi Kependudukan.

[17]2007." Cara membuat grafik dengan excel". www.kampusexcel.com/cara-membuat-grafik-di excel-2007.html. Diunduh 16 September 2016.

[18]2010. "Analisis data Kependudukan Desa Darmaga."http://selvias08.student.ipb.ac.id/2010/06/19/analisisdata-kependudukan-desa-dramaga. Diunduh 10 September 2016. 